\title{
Safe and effective disinfection of show cave infrastructure in a time of COVID-19
}

\author{
Hazel A. Barton (D) \\ Department of Biology, University of Akron, Akron, OH 44325-3908, USA
}

\begin{abstract}
The COVID-19 pandemic, caused by the novel coronavirus SARS-CoV-2, has been responsible for over 650,000 deaths worldwide. Transmission of SARS-CoV-2 occurs primarily through airborne transmission or direct human contact, demonstrating the importance of social distancing measures and the use of face masks to prevent infection. Nonetheless, the persistence of coronavirus on surfaces means that disinfection is important to limit the possibility of contact transmission. In this paper, the potential for various surfaces in show caves to serve as sources for SARS-CoV-2 infection is examined. Given the isoelectric potential $(\mathrm{pl})$ of SARS and SARS-like coronaviruses, it is likely that they are adsorbed via electrochemical interactions to (limestone) rock surfaces, where the high humidity, $\mathrm{pH}$ and presence of biocarbonate ions will quickly lead to inactivation. Nonetheless, show caves contain infrastructure made of other non-porous surfaces that are more permissive for maintaining coronavirus viability. The 423 antiviral products approved by the US Environmental Protection Agency (EPA) were curated into 23 antiviral chemistries, which were further classified based on their potential to be hazardous, impact cave features or ecosystems, and those compounds likely to have the minimum impact on caves. The results suggest that alcohols ( $70 \%$ ethanol), organic acids (citric and lactic acid) and dilute hypochlorite represent the best disinfectants for in-cave use on non-porous surfaces. These disinfectants are able to inactivate coronaviruses in $<5$ min with minimal impact to cave features and ecosystems.
\end{abstract}

Keywords: COVID-19, SARS-CoV-2, coronavirus, caves, disinfection

Received 3 June 2020; Revised 25 July 2020; Accepted 26 July 2020

Citation: Barton H.A., 2020. Safe and effective disinfection of show cave infrastructure in a time of COVID-19. International Journal of Speleology, 49 (2), 137-147. Tampa, FL (USA) ISSN 0392-6672 https://doi.org/10.5038/1827-806X.49.2.2332

\section{INTRODUCTION}

In December, 2019 a cluster of seven patients suffering from an unusual pneumonia were admitted to the Jin Yin-Tan Hospital in Wuhan, Hubei Province, China (Zhou et al., 2020). Samples from five of these patients were shown to contain a novel coronavirus, initially termed 2019-nCoV (Zhou et al., 2020). Subsequent sequencing of the genome of this novel coronavirus demonstrated its high degree of similarity to the virus responsible for the 2003 SARS outbreak, and the virus was renamed SARS-CoV-2 (CoVICTV, 2020). This novel coronavirus is responsible for a complex range of symptoms, characterized by a persistent dry cough and fever, which can rapidly progress to a severe disease (termed COVID-19) and death, particularly in patients aged $>60$ years (CDC Covid-19 Response Team, 2020; WHO, 2020).

The sustained, person-to-person spread of SARS-CoV-2, exacerbated by a high incidence of asymptomatic spread (James et al., 2020) has led to a global pandemic, with an excess of 16 million known infections and over 650,000 deaths worldwide (Dong et al., 2020), although serology studies suggest the actual number of cases may exceed this number by 25- to 50-fold (Bendavid et al., 2020; Wilson, 2020). In order to limit the spread of SARS-CoV-2, the US Centers for Disease Control and Prevention (CDC) have published a series of guidelines that include social distancing, frequent handwashing and the wearing of masks in public (for example, see: https:// www.cdc.gov/coronavirus/2019-ncov/preventgetting-sick/index.html). Within the United States, many states also implemented 'stay at home' orders, with re-opening occurring on a state-by-state timeline (Adolph et al., 2020; Courtemanche et al., 2020).

Among the many businesses that have been impacted by these 'stay at home' orders are commercial show caves, which allow the general public to visit caves under relatively safe conditions, including artificial lighting and walkways. Worldwide there are an estimated 1,500 show caves (Spate \& 
Spate, 2014), with over 300 caves in the US. These include commercial caves, along with federal and state managed operations. In a 2013 survey, the 142 commercial show caves of the US National Caves Association, demonstrated an economic impact of $>\$ 220$ million in annual revenue (Petrick \& Chen, 2013), while commercial caves managed by the US National Park Service generate almost \$500 million (Cullinane Thomas \& Koontz, 2020). With almost 20 million visitors annually, these show caves provide important educational and outreach activities related to the history, geology and protection of cave biota in the subsurface (Petrick \& Chen, 2013).

Given the size of tour groups, relatively confined conditions and potentially limited ventilation of caves, reopening cave tours will require managers to adapt to challenging social distancing and personal protective equipment (PPE) recommendations (CDC, 2020). An added complexity is related to how to disinfect artificial cave infrastructure (such as handrails and doors handles), while limiting the impact to native ecosystems, which can be particularly sensitive to chemical input (Barton, 2015). Human coronaviruses are not novel, and it is estimated that coronaviruses have been circulating within the human population for over 1,000 years (Pyrc et al., 2006; Woo et al., 2009). Before the emergence of SARS-CoV-2, there were three circulating human coronaviruses ( $\mathrm{HCoV})$ : two (HCoV-229E and $\mathrm{HCoV}-\mathrm{OC} 43)$ are responsible for up to $30 \%$ of common colds, while HCoV-NL63 is associated with respiratory diseases in children (van der Hoek et al., 2004). Given the ubiquitous nature of these viruses, coronavirus inactivation has historically been included in the evaluation of many commercial and household disinfectants.

While many commercial caves have adopted protocols to disinfect surfaces and equipment to prevent the spread of White-nose Syndrome in bats, these approaches (which were developed to inactivate fungal spores), are much more aggressive than are necessary to inactivate an enveloped coronavirus (Maris, 1990; Shelley et al., 2012). Indeed, exposure of SARS-CoV-2 to environmental conditions can lead to viral inactivation in as little as 3 hours, while coronaviruses are up to 500-times more sensitive to disinfectants as non-enveloped viruses (Maris, 1990; van Doremalen et al., 2020). Nonetheless, in order to ensure the safety of visitors to show caves, it is important to disinfect surfaces that are expected to be touched by visitors. This paper examines the known chemistry and sensitivity of human coronaviruses to disinfectants and provides a number of recommendations for effective disinfection, while limiting potential impact to the cave environment.

\section{MATERIALS AND METHODS}

To calculate the pI of coronaviruses, viral protein sequences were obtained from the National Center for Biotechnology Information (NCBI) protein database in translated FASTA format (https://www.ncbi.nlm.nih. gov/protein), including those for which whole viral particle pI have been determined empirically. These sequences included the enteric bovine coronavirus spike protein (Bovine_CoV; accession NP_150077), rat sialodacryoadenitis coronavirus spike protein (RCoV-SDAV; accession AAF97738), bat SARS-like betacoronavirus spike protein (BCoV-SARS; accession ATO98157), bat SARS-like betacoronavirus BtRs spike protein (BCoV-BtRs; accession QDF43825), bat SARS-like betacoronavirus RaTG13 spike protein (BCoV-RaTG13; accession QHR63300), human betacoronavirus spike protein (HCoV-OC43; accession YP_009555241), human betacoronavirus SARSCoV 2003 Urbani isolate spike protein (SARS-CoV; accession AAP13441), human betacoronavirus SARSCoV-2 type isolate Wuhan-Hu-1 spike protein (SARSCoV-2 Wuhan-Hu-1; accession YP_009724390), human betacoronavirus SARS-CoV-2 Australian isolate spike protein (SARS-CoV-2 Australian; accession QJR88869), human betacoronavirus SARS-CoV-2 Jamaican isolate spike protein (SARSCoV-2 Jamaica; accession QJX70646), human betacoronavirus SARS-CoV-2 New York City isolate spike protein (SARS-CoV-2 CDC/USA; accession QJQ27937), 1918 influenza A H1N1 hemagglutinin (1918 Influenza H1N1; accession AAD17229), 2015 influenza A H5N8 hemagglutinin (2015 Influenza H5N8; accession ALB07770), 2009 swine influenza A H1N1 hemagglutinin (2009 Swine Flu H1N1; accession ACD88516), rabies lyssavirus wolf isolate surface glycoprotein (Rabies; accession AJP77607), human poliovirus 1 strain Sabin VPO polyprotein (accession CAA24465). The isoelectric point was calculated using the IPC isoelectric point calculator, which uses 16 different algorithms to calculate pI (Kozlowski, 2016). The average pI was plotted versus protein molecular weight $(\mathrm{kDa})$ in Excel and imported into Adobe Illustrator 2020 to create the final plot.

The US Environmental Protection Agency (EPA) List $\mathrm{N}$ registry of disinfectants for use against SARSCoV-2 was used to identify antiviral disinfectants based on active ingredient (https://cfpub.epa.gov/ giwiz/disinfectants/index.cfm). The activity of each compound against coronaviruses or enveloped viruses in general was based on established antiviral activity, with human health impact determined by cross-referencing to a toxicology database (Poli et al., 1979; McDonnell \& Russell, 1999; Wolff et al., 2005; Bateman et al., 2014; Kampf et al., 2020).

\section{RESULTS}

To date the majority of SARS-CoV-2 infections in humans occur through direct human contact or through respiratory droplets and aerosols (Prather et al., 2020; Santarpia et al., 2020; Stadnytskyi et al., 2020). Nonetheless, the detection of SARS-CoV-2 on surfaces means that they can provide a potential source for contact transmission, particularly in the case of non-porous surfaces, such as plastics, glass and metal (Sattar \& Springthorpe, 1996; Wolff et al., 2005; Dietz et al., 2020; van Doremalen et al., 2020; Santarpia et al., 2020). The likelihood of porous surfaces, such as the host rock (limestone) of the cave to serve as a potential surface for contact transmission 
was examined by comparing the known geochemistry of calcite with coronavirus particle chemistry.

Broadly, the isoelectric point (pI) is a measure of average charge. While the pI is generally calculated or measured for individual proteins to determine the strength of electrostatic interactions, it has also been used to determine the sorption characteristics of whole virus particles (virions) to mineral surfaces (Miller et al., 1944; Carlson Jr et al., 1968; Moore et al., 1981). In this study, the pI of coronaviruses, SARS-like coronaviruses and SARS-CoV/SARSCoV-2 surface proteins were compared to other enveloped RNA viruses where empirical pI values also exist (Fig. 1). In the case of influenza A virus, the pI was calculated based on the dominant surface protein, hemagglutinin, to obtain a value of $6.0-6.8$ depending on viral strain, which included the source of the 1918 Spanish flu pandemic, the 2009 swine flu pandemic, and a 2015 bird flu (Fig. 1). As influenza includes other surface proteins along with a negatively charged phospholipid bilayer, this obtained value was compared to the measured pI for the entire viral particle, which is 5.0 to 5.9 (Miller et al., 1944; Vajda et al., 2016). Similar to coronaviruses, rabies has a dominant glycoprotein with a calculated pI of 7.6 (Fig. 1), which has been measured as pI 7.0 for the whole viral particle (Atanasiu et al., 1979). Therefore, while the dominant surface proteins cannot give a net surface charge for the whole virus particle, the pI values likely underestimate the net negative charge of the virus by $0.5-1.0$ pI units (Lakshminarayanaiah $\&$ Murayama, 1975; Pekker \& Shneider, 2015).

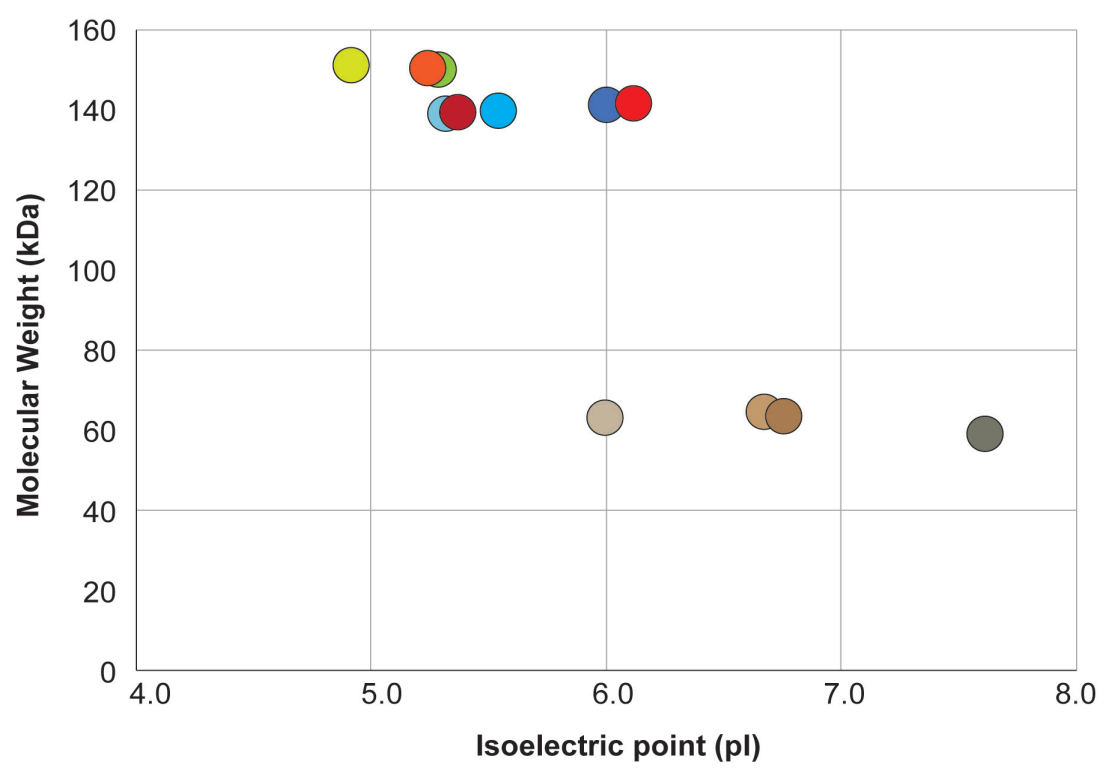

Coronaviruses

\begin{tabular}{ll} 
Animal & \multicolumn{1}{c}{$\begin{array}{c}\text { Human } \\
\text { RCoV-SDAV }\end{array}$} \\
HCoV-OC43 \\
Bovine-CoV & SARS-CoV \\
BCoV-RaTG13 & SARS-CoV-2 \\
BCoV-SARS & $\begin{array}{l}\text { Type strain: Wuhan-Hu-1 } \\
\text { Australian isolate: March 2020 } \\
\text { Jamaican isolate: March 2020 }\end{array}$ \\
BCoV-BtRs & CDC/USA isolate: March 2020
\end{tabular}

Fig. 1. Calculated isoelectric point (pl) values versus molecular weight for the dominant surface proteins of enveloped RNA viruses, including coronaviruses, influenza A and rabies. The average calculated pl is plotted for these viruses, along with the measured, whole virion particle pl values for influenza A and rabies.

For coronaviruses, the pI of the spike protein was determined for animal coronaviruses (bovine and rat), along with circulating human betacoronavirus (HCoVOC43), the SARS-like bat coronaviruses (BCoV_ RaTG13, BCoV-SARS and BCoV-BtRs) and human SARS viruses (SARS-CoV/SARS-CoV-2). In the case of SARS-CoV-2, representative virus spike proteins were used from four geographically separate isolates (Fig. 1). The data indicate a consistent clustering of the coronaviruses with a pI between 4.9 and 6.1, although as stated, due to membrane chemistry, this value is likely to be lower for the whole virus particle (Pekker \& Shneider, 2015). These data suggest that the SARS and SARS-like coronaviruses have a net negative charge, which will result in a strong electrostatic attraction between the virus and calcium carbonate surfaces, such as limestone and concrete.

There are a number of artificial, non-porous surfaces (plastics, metal and glass) in show caves that form the tour infrastructure (i.e., handrails and door handles). Given that coronaviruses can persist longer on these surfaces, especially at cooler temperatures and in the absence of sunlight, these surfaces should be disinfected to limit the possibility of contact spread (Wolff et al., 2005; Kampf et al., 2020;
Ratnesar-Shumate et al., 2020). An evaluation of the 423 products recommended by the US EPA for use against SARS-CoV-2 was carried out. This multitude of products was reduced to 27 antiviral chemistries (Table 1), of which four were removed from further consideration: the antimicrobial activity of sodium chloride depends on its interaction with hypochlorous acid to produce sodium hypochlorite, sodium carbonate is used to stabilize sodium hypochlorite, and ammonium carbonate and bicarbonate are used as $\mathrm{pH}$ neutralizing agents (McDonnell \& Russell, 1999). The remaining 23 antiviral chemistries were further grouped into four categories for the potential of in-cave use based on potential impact descriptions: 1) potentially toxic under cave conditions; 2) chemical impact; 3) reduced impact; and 4) lowest impact (Table 1). As a reference, mechanism of action in viral inactivation (mechanism), effective concentrations (active concentration) and contact time for antiviral activity (contact time) by these chemistries are shown.

\section{Potentially toxic}

A number of the oxidants recommended by the EPA should be avoided in cave settings due their strong biocidal activities, which can either negatively affect 


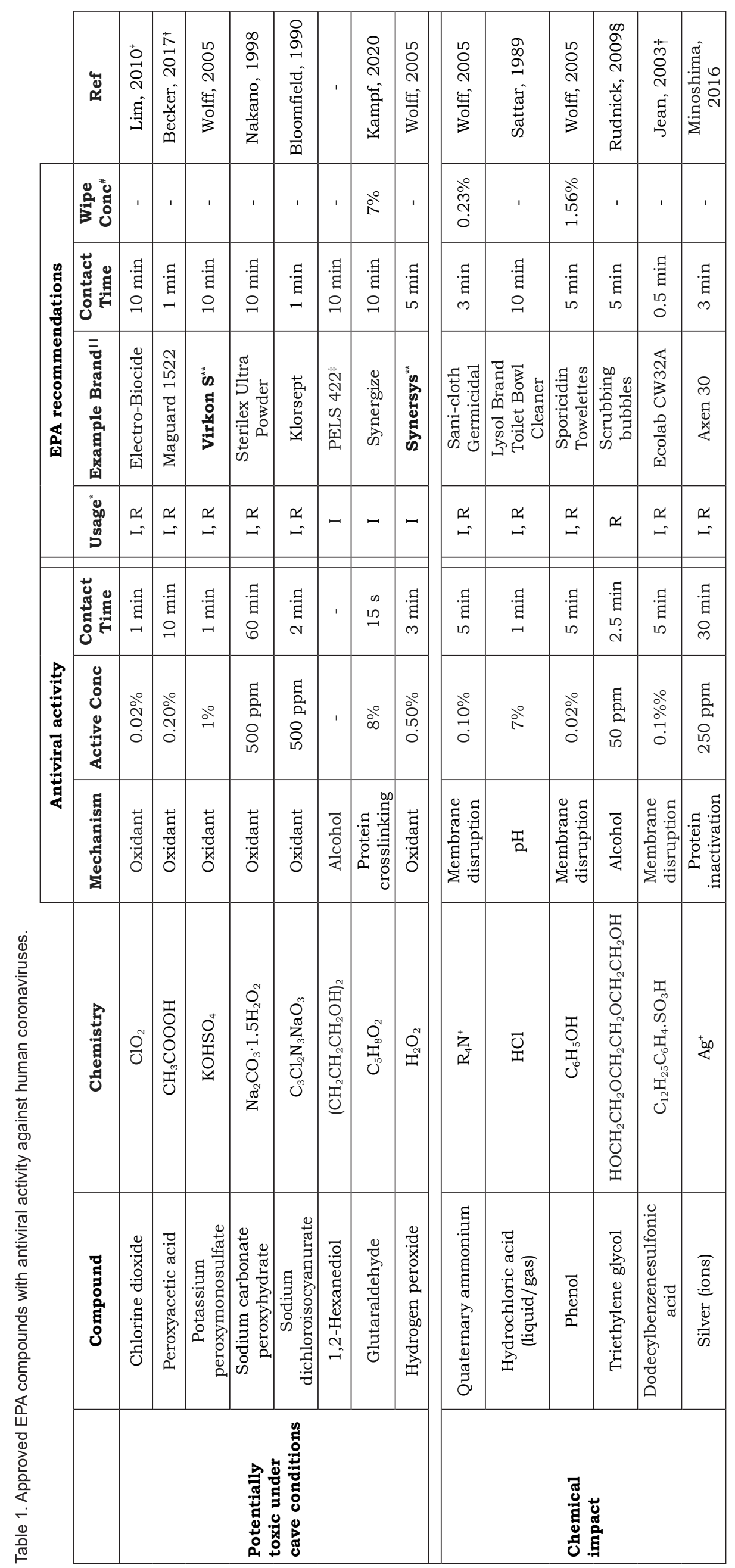




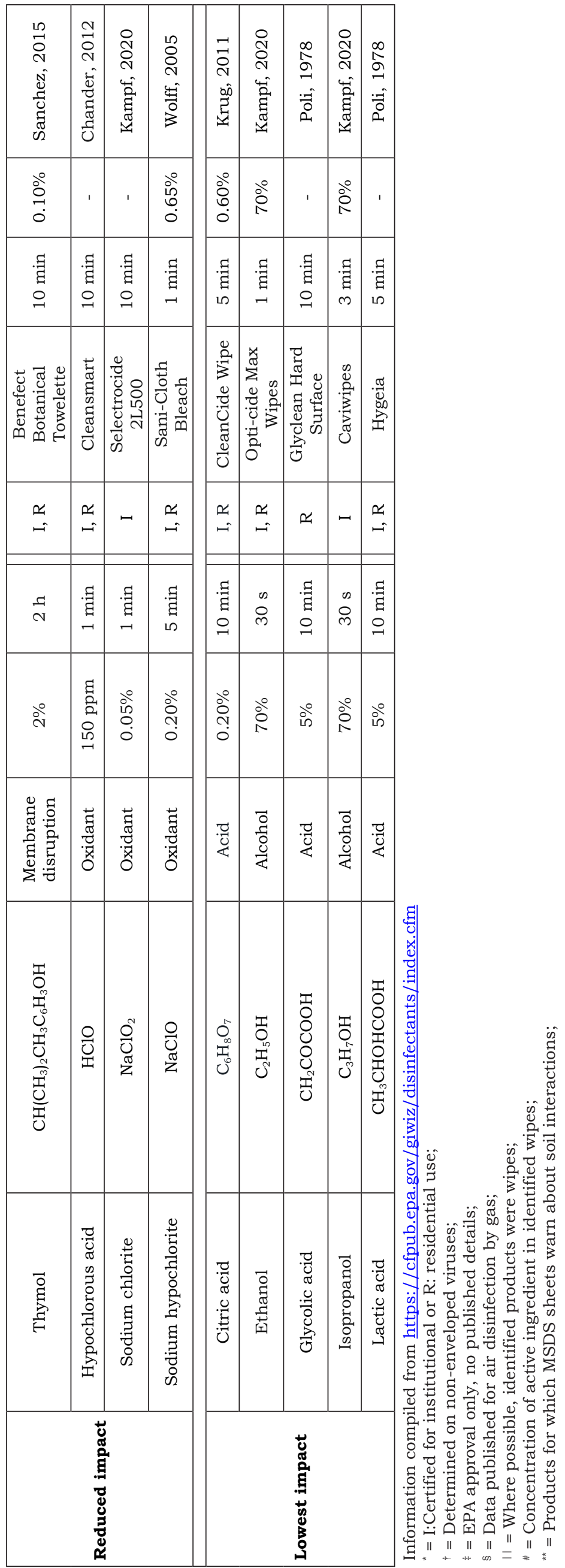


endemic species (and human visitors), or are highly corrosive (McDonnell \& Russell, 1999). Indeed, many of these compounds are only recommended for use in healthcare or industrial settings due to such safety considerations. Of these oxidants, chlorine dioxide can produce a poisonous gas at room temperature, and even at low concentrations is a strong irritant of mucous membranes (Bateman et al., 2014). Similar oxidants include peroxyacetic acid, potassium peroxymonosulfate, sodium corbanote peroxyhydrate, and sodium cholorisocyanurate (McDonnell \& Russell, 1999; Bateman et al., 2014). While glutaraldehyde and 1,2-hexanediol are effective disinfectants at low concentrations, without adequate ventilation (as would be expected in cave environments) they have the potential to be strong irritants (Bateman et al., 2014). Finally, while hydrogen peroxide breaks down into the relatively inert oxygen and water, it is highly corrosive and reacts with iron in the Fenton reaction to generate dangerous hydroxyl radicals that cause severe damage in biological molecules, and DNA in particular (Rafat Husain et al., 1987; Winterbourn, 1995). Cave sediments commonly contain iron-oxides (comprised of goethite and ferrihydrite) as a residue of past cave-forming processes, which give cave sediments and muds their characteristic brown-tored coloration (Palmer, 2007; White, 2007; Blatnik et al., 2020). Indeed, these iron-rich deposits have proven invaluable in paleomagnetic studies to age many cave features (Luiszer, 2009; Blatnik et al., 2020). The average iron content of cave sediments has been estimated to range between 0.1-2.0\% (Sasowsky \& Mylroie, 2004; Sasowsky, pers. comm., 2020), and given that $\mathrm{Fe}$ (III) can be recycled to $\mathrm{Fe}(\mathrm{II})$ by microbial activity in cave sediments, this suggests that even trace iron in the environment is sufficient to catalyze the Fenton reaction (Schwertmann, 1991; Parker et al., 2018).

\section{High impact}

Several of the compounds recommended for disinfection have the potential for a significant impact on the cave environment, either through interactions with host rock chemistry or microbial ecosystems. With regard to host rock chemistry, hydrochloric acid is an aggressive acid that readily dissolves limestone and is particularly problematic in regard to speleothem damage. Caves are also nutrient-limited environments, particularly in regard to nitrogen (Barton, 2015), and while a number of ammoniumbased compounds are likely to be safe and effective, the introduction of excess nitrogen can be particularly detrimental to microbial system dynamics (Barton, 2015; Hershey \& Barton, 2018). A notable example of such impact is in Lascaux Cave, where introduced quaternary ammonium compounds (quats) has resulted in excessively high nitrogen content in cave sediments, dramatically altering the normal microbiology of the cave and leading to damage to the important Neolithic paintings (Bastian et al., 2009). Similarly, the low levels of organic carbon found in caves $(<0.5 \mathrm{mg} / \mathrm{L})$ makes them sensitive to organic input (Barton, 2015). A number of the recommended disinfectants are based on reactive aromatic and longchain hydrocarbons (including phenol, triethylene glycol, and dodecylbenzenesulfonic acid), which are likely to introduce unreasonably high levels of organic carbon contamination (Barton, 2015). Finally, while transition metals are common trace elements in limestone, silver ions (which have strong antimicrobial activity) are not naturally broken down, leading to extended contamination in sediments and resultant changes in microbial community structure (Klaine et al., 2008).

\section{Reduced impact}

The EPA disinfectant list contains a number of effective compounds that are likely to have other, undesired consequences. Among these is thymol, which has a strong, antiseptic odor, while a 1:10 solution of household bleach (hypochlorite), sodium chlorite or hypochlorous acid (which dissociate to form hypochlorite) have a strong chlorine smell that can be intense without adequate ventilation. Thus, while these compounds are safe and effective at low concentrations, their use may be limited simply through the tolerance of visitors and staff.

\section{Lowest impact}

The EPA list contains a number of antimicrobial agents that have chemistries similar to organic compounds naturally found in caves, including citric and lactic acid (Bullen et al., 2008). These compounds are made during microbial metabolic processes (overflow metabolism) and include alcohols, allowing them to be easily broken down by native microbial communities (Xu et al., 1999; Vemuri et al., 2006); however, as with other organic carbon, their excessive use will alter microbial community structure (Barton, 2015; Hershey \& Barton, 2018). Such compounds also have the least likelihood of being problematic if tourists were to pick them up on their hands, for example, citric acid is found in oranges, while ethanol and isopropanol quickly volatilize into the atmosphere.

\section{DISCUSSION}

One of the concerns regarding COVID-19 in caves was the potential of SARS-CoV-2 to survive longterm under the temperature, humidity and low light conditions of caves, including whether the rock surfaces could serve as a source of possible transmission (R. Toomey, personal communication, 2020). While there are currently no studies that have specifically examined the persistence of coronaviruses in caves, these viruses have been tested under a number of conditions that mimic the cave environment. Human coronaviruses (HCoV-229E and OC43) and SARSCoV have been shown to rapidly lose infectivity in high humidity (>50\%) (Kim et al., 2007; Chan et al., 2011; Dietz et al., 2020). This inactivation is believed to occur through two processes: 1) high humidity prevents the dehydration of droplets to reduce particle size, which is necessary for the virus to remain buoyant and promote person-to-person spread (Stadnytskyi et al., 2020); and 2) high humidity destabilizes the polar residues 
in the viral envelope, which is critical to maintaining viral infectivity (Yang \& Marr, 2012). Given the high humidity of caves environments (>95\%), this suggests rapid inactivation will occur (Wigley \& Brown, 1976). Nonetheless, coronaviruses do persist longer at cooler temperatures and in the absence of sunlight, and the impact of high relative humidity and geochemistry should not be considered an inherent inactivation approach that negates the need to disinfect surfaces that visitors touch (Ratnesar-Shumate et al., 2020; van Doremalen et al., 2020).

A significant amount of work has explored virus adsorption and inactivation in mineral substrates, particularly for poliovirus, which was historically a dangerous groundwater pathogen (Poli et al., 1979; Murray \& Parks, 1980; Moore et al., 1981). Poliovirus has a calculated capsid pI of 6.4 and a measured pI of 5.9, similar to that of coronaviruses (Carlson Jr et al., 1968; Murray \& Parks, 1980). The anionic surface charge (net negative charge) of the virus predicts how the particle will interact and adsorb to surfaces, which is governed by general electrodynamic potentials (Murray \& Parks, 1980). The surface charge of limestone is derived from the potential of the ions in solution on the surface of the rock, which is dominated by the cation $\mathrm{Ca}^{2+}$ (although $\mathrm{HCO}_{3}{ }^{-}, \mathrm{CO}_{3}{ }^{2-}$, $\mathrm{H}^{+}$and $\mathrm{OH}^{-}$ions contribute to surface chemistry), and has been empirically shown to have a pI between 8.0 to 9.5 , with commonly measured $\mathrm{pH}$ values of 8.3 (Somasundaran \& Agar, 1967; Banks et al., 2010). This net positive charge will strongly attract negatively charged coronavirus particles, with electrochemical interactions causing strong adsorption through hydrogen bonding and van der Waals forces (Murray and Parks, 1980). The stronger the difference in electrochemical charge between surfaces (with pI as a proxy) the stronger this attraction, which will outweigh the impact of $\mathrm{pH}$ (Carlson Jr et al., 1968; Murray and Parks, 1980; Moore et al., 1981). Indeed, strong poliovirus attraction has been demonstrated on positively charged iron oxide and dolomite surfaces, indicating that limestone surfaces and iron-rich cave sediments are capable of binding high levels of SARSCoV-2 particles (Murray \& Parks, 1980; Moore et al., 1981). Further, bicarbonates and high $\mathrm{pH}(>8.0)$ readily inactivate coronaviruses, both of which are satisfied on limestone surfaces (Moore et al., 1981; Lamarre \& Talbot, 1989).

Past work on disinfection in cave environments have been focused on WNS disinfection or the removal of algal and cyanobacterial growth around artificial lighting (lampenflora; Boston, 2006; Mulec \& Kosi, 2009; Shelley et al., 2012; Meyer et al., 2017). Among the disinfectants identified for use against SARSCoV-2, only quaternary ammonium compounds and hypochlorite were recommended for WNS disinfection protocols (Table 1), while hypochlorite and high concentrations of hydrogen peroxide (15 wt/\%) are recommended for lampenflora (Shelley et al., 2012; Meyer et al., 2017). Enveloped viruses are much more sensitive to inactivation than fungal spores or algal cysts and such aggressive approaches to disinfection are unnecessary (Maillard, 2001). Indeed, enveloped viruses such as coronaviruses are 500-times more sensitive to hypochlorite than non-enveloped viruses, and are also sensitive to a range of chemistries that would have no impact on WNS or algae, including weak acids, alkalis, or alcohol-dehydration (Table 1; Poli et al., 1979; Wolff et al., 2005; Kampf et al., 2020). This provides a variety of compounds that have the potential to inactive coronaviruses on surfaces and prevent contact transmission, as indicated by the 423 products identified by the EPA.

\section{Special consideration on the use of hydrogen peroxide}

Past researchers have recommended the use of hydrogen peroxide in caves, due to its lack of odor and ability to break down into inert $\mathrm{H}_{2} \mathrm{O}$ and $\mathrm{O}_{2}$ (Boston, 2006; Boston et al., 2006; Mulec \& Kosi, 2009); however, in the presence of reduced or oxidized iron, the Fenton reaction produces hydroxyl radicals (Eq. 1) and other reactive species (including hydroxides and hydroperoxyls; Eq. 2):

$$
\begin{aligned}
& \mathrm{Fe}^{2+}+\mathrm{H}_{2} \mathrm{O}_{2} \rightarrow \mathrm{Fe}^{3+}+\mathrm{HO}^{\circ}+\mathrm{OH}^{-} \\
& \mathrm{Fe}^{3+}+\mathrm{H}_{2} \mathrm{O}_{2} \rightarrow \mathrm{Fe}^{2+}+\mathrm{HOO}^{\circ}+\mathrm{H}^{+}
\end{aligned}
$$

The reactive species are dangerous to biological systems, causing extensive DNA damage and mutagenesis, even at pmol concentrations (Winterbourn, 1995). This activity can be accentuated in cave environments by the microbially-enhanced dissolution of iron oxides, which is promoted under the mineral grain size and chemistry of iron-rich sediments similar to those in caves (Schwertmann, 1991; Parker et al., 2018). Indeed, in the past, researchers who have demonstrated the successful use of hydrogen peroxide to remove lampenflora, only did so when high concentration solutions (>15\%) were used, which required the use of protective respirators and goggles given the poor ventilation in caves and noxious gases produced (Meyer et al., 2017). Given the extreme reactivity and corrosive activity of hydrogen peroxide (which can attack limestone surfaces as well as metals; Mulec \& Kosi, 2009) and given that even trace levels of hydroxyl radicals can be acutely toxic (one of the reasons human cells have such effective iron-scavenging mechanisms is limit the Fenton reaction from the tiny amounts of $\mathrm{H}_{2} \mathrm{O}_{2}$ generated during cellular respiration; Barbouti et al., 2001; Imlay, 2008), extreme caution should therefore be used if choosing to use hydrogen peroxide in caves, as highlighted by the MSDS sheets for these products: when compiling the MSDS data for Table 1, only the strong oxidant potassium peroxymonosulfate (Virkon S) and hydrogen peroxide (Synersys) contain explicit warnings to avoid interaction with soils (for example, compare http://www.fourupack.com/myfile. aspx?doc $=48328$ SynersysSporicidalDisinfectantP ART_A_and_B_SDS.pdf\%7c2 and https://media3. cleanfreak.com/documents/sds/lysol-all-purposecleaner-with-bleach.pdf). Nonetheless, all of the chemicals on the EPA List $\mathrm{N}$ are effective against coronaviruses and hydrogen peroxide may be appropriate for use on glass or plastic surfaces if their reaction with cave sediments is prevented. 


\section{CONCLUSIONS}

To date, there are no recorded cases of COVID-19 transmission have been identified as the result of surface contact transmission (Dietz et al., 2020) and the majority of cases can be traced to airborne transmission or direct human contact, demonstrating the importance of social distancing measures and the use of face masks (Prather et al., 2020; Santarpia et al., 2020; Stadnytskyi et al., 2020). The calculated pI of SARS-CoV-2 suggests that in caves the virus would be adsorbed onto limestone surfaces, further reducing the likelihood that these surfaces could serve as a source of virus transfer (Fig. 1). In addition, the high humidity of caves and chemistry of limestone surfaces (including inactivating bicarbonates and high $\mathrm{pH}$ ) are likely to rapidly inactivate adsorbed coronavirus particles, suggesting that the limestone/ rock surfaces or concrete walkways pose no specific danger for contact transmission. Nonetheless, nonporous surfaces (such as plastics, metals and glass) are more permissive to coronavirus viability and tourist operators should focus on disinfection of infrastructure from these materials that visitors will touch. Given the 423 antiviral agents recommended by the EPA, the following compounds are recommended for use in caves (Table 1):

Alcohols: Ethanol is naturally produced by microbial metabolism and has been shown to sorb to calcium carbonate, suggesting it is common in caves (Bullen et al., 2008). An effective concentration of $70 \%$ ethanol will inactivate coronaviruses by dehydration in $5 \mathrm{~min}$ (Wolff et al., 2005).

Organic acids: The viral cell envelope of coronaviruses is particularly sensitive to destabilization by acids (Poli et al., 1979; Lamarre \& Talbot, 1989). These organic acids, such as citric acid, share similarity in chemistry to organic acids that are naturally found in caves (Bullen et al., 2008)

Hypochlorite: While hypochlorite can produce a chlorine smell, even at low concentrations hypochlorite is one of the most effective disinfectants against coronaviruses (Maillard, 2001): a 1:50 dilution of household bleach (final concentration $0.12 \%$ ) will inactivate coronaviruses in $<5$ min (Maillard, 2001; Wolff et al., 2005). While chlorine ions are likely to impact cave fauna (Boston, 2006), a study using $0.5 \% \mathrm{HOCl}$ to treat lampenflora (which is higher than the recommended $0.1 \%$ to inactivate coronaviruses) demonstrated no increased impact on a cave adapted indicator species (the springtail Tomocerus celsus; Meyer et al., 2017). Others have suggested that hypochlorite leaves an oxidizing residue within caves (Boston et al., 2006). The reaction of hypochlorite with limestone (Eq. 3):

$$
\mathrm{CaCO}_{3}+2 \mathrm{NaOCl} \rightarrow \mathrm{Na}_{2} \mathrm{CO}_{3}+\mathrm{Ca}(\mathrm{ClO})_{2}
$$

produces sodium bicarbonate and calcium hypochlorite. While calcium bicarbonate is fairly innocuous (and is a common food additive), calcium hypochlorite is more reactive and is used as a whitening agent in laundry detergent (it is identified as a white, powdery residue that smell weakly of bleach when scratched). Under acidic conditions, calcium hypochlorite is protonated to hypochlorous acid, which is a strong oxidant; however, limestone buffers the surface chemistry to an alkaline $\mathrm{pH}$ 8.3. Thus, while care should be taken to avoid generating conditions that produce high concentrations of hypochlorite in caves, the underlying chemistry of bleach in caves is preferable to the nitrogen introduction of quats and much safer than the potential damage of hydrogen peroxide to human health.

In recommending these compounds for in-cave use, it should be noted that all disinfectants have the ability to negatively impact cave microbiota (Estévez et al., 2019). To limit the unnecessary introduction of these compounds into caves, the lowest concentration necessary to inactivate SARS-CoV-2 should be used (Table 1), as increased concentrations provide no additional antiviral activity, and in the case of alcohols, higher concentrations actually have reduced antiviral activity. To limit impact, disinfecting wipes have a number of advantages over the use of sprayed liquid disinfectants, these include: 1) stabilization of disinfection chemistry in wipes means that they are lesslikely to produce aerosols or off gas into the environment, particularly in the case of flammable substrates (Tyan et al., 2019); 2) wipes contain disinfectants that have already been diluted to the working concentration on an appropriate adsorbant, reducing the likelihood of excessive chemical introduction; 3) wipes are convenient to carry into the caves (including on tours) and are unlikely to unnecessarily introduce chemicals or organics to the environment through spraying or accidental spills; and 4) the use of wipes are unlikely to leave excessive residues on surfaces.

The recommended disinfectants in Table 1 have been curated to identify those available as wipes, including the advised contact time for coronavirus inactivation and concentration of active ingredient (derived from the MSDS) for each chemistry when compared to published laboratory inactivation studies. In many cases, due to the underlying chemistry, wipes may not appropriate (Table 1), are unavailable during the epidemic, or may not represent a cost-effective approach to disinfection. In this case, the full list of EPA database, which is searchable using active ingredients, should be used to identify alternatives (https://www.epa.gov/pesticide-registration/list-ndisinfectants-use-against-sars-cov-2). Regardless of choice, these procedures are suggested to limit the potential for contact transmission of SARS-CoV-2 in a way that minimizes impact on the cave ecosystem; however, given the generally poor ventilation in caves, they in no way negate the continued need for social distancing and face masks to limit transmission of this dangerous virus.

\section{ACKNOWLEDGEMENTS}

The author thanks Reilly S. Blackwell for her assistance with summing up the EPA disinfection list. The author would like to thank three anonymous reviewers whose comments increased the quality and relevance of the manuscript. 
Authorship statement: The author collected the data, carried out the analyses and wrote the manuscript.

\section{REFERENCES}

Adolph, C., Amano, K., Bang-Jensen, B., Fullman, N., Wilkerson, J., 2020. Pandemic politics: Timing statelevel social distancing responses to COVID-19. Posted March 30, 2020 medRxiv.

https://doi.org/10.1101/2020.03.30.20046326

Atanasiu, P., Perrin, P., Favre, S., Sisman, J., 1979. Glycosylation and isoelectric properties of complete and defective rabies viruses. Annuals of Microbiology, 130A, 85-101.

Banks, E.D., Taylor, N.M., Gulley, J., Lubbers, B.R., Giarrizo, J.G., Bullen, H.A., Hoehler, T.M., Barton, H.A., 2010. Bacterial calcium carbonate precipitation in cave environments: a function of calcium homeostasis. Geomicrobiology Journal, 27, 444-454.

https://doi.org/10.1080/01490450903485136

Barbouti, A., Doulias, P.T., Zhu, B.Z., Frei, B., Galaris, D., 2001. Intracellular iron, but not copper, plays a critical role in hydrogen peroxide-induced DNA damage. Free Radical Biology and Medicine, 31, 490-498.

https://doi.org/10.1016/S0891-5849(01)00608-6

Barton, H.A., 2015. Starving artists: Bacterial oligotrophic heterotrophy in caves. In: Engel, A.S. (Ed.), Life in extreme environments: Microbial life of cave systems. DeGruyter, Berlin, Germany, 350 p.

Bastian, F., Alabouvette, C., Jurado, V. and Saiz-Jimenez, C., 2009. Impact of biocide treatments on the bacterial communities of the Lascaux Cave. Naturwissenschaften, 96, 863-868.

https://doi.org/10.1007/s00114-009-0540-y

Bateman, N., Jefferson, R., Thomas, S., Thompson, J., Vale, A. (Eds.), 2014. Oxford Desk Reference: Toxicology. Oxford University Press, Oxford, UK, 416 p. https://doi.org/10.1093/med/9780199594740.001.0001

Becker, B., Brill, F.H.H., Todt, D., Steinmann, E., Lenz, J., Paulmann, D., Bischoff, B., Steinmann, J., 2017. Virucidal efficacy of peracetic acid for instrument disinfection. Antimicrobial Resistance and Infection Control, 6, 114.

https://doi.org/10.1186/s13756-017-0271-3

Bendavid, E., Mulaney, B., Sood, N., Shah, S., Ling, E., Bromley-Dulfano, R., Lai, C., Weissberg, Z., Saavedra, R., Tedrow, J., 2020. COVID-19 antibody seroprevalence in Santa Clara County, California. Posted April 30, 2020 MedRxiv. https://doi.org/10.1101/2020.04.14.20062463

Blatnik, M., Culver, D.C., Gabrovšek, F., Knez, M., Kogovšek, B., Kogovšek, J., Liu, H., Mayaud, C., Mihevc, A., Mulec, J. \& Năpăruş-Aljančič, M., 2020. Significant findings from karst sediments research. In: Knez, M., Otoničar, B., Petrič, M., Pipan, T., Slabe, T. (Eds.), Karstology in the classical karst. Springer, Switzerland, p. 93-113. https://doi.org/10.1007/978-3-030-26827-5 4

Bloomfield, S.F., Smith-Burchnell, C.A., Dalgleish, A.G., 1990. Evaluation of hypochlorite-releasing disinfectants against the human immunodeficiency virus (HIV). Journal of Hospital Infection, 15, 273-278. https://doi.org/10.1016/0195-6701(90)90035-M

Boston, P.J., 2006. To bleach or not to bleach: algal control in show caves. In: Hildreth-Werker, V., Werker, J.C. (Eds.), Cave conservation and restoration. National Speleological Society, Huntsvile, AL, 600 p.

Boston, P.J., Northup, D.E., Lavoie, K.H., 2006. Protecting microbial habitats: Preserving the unseen. In: Hildreth-
Werker, V., Werker, J.C. (Eds.), Cave conservation and restoration. National Speleological Society, Huntsvile, AL, p. 600.

Bullen, H.A., Oehrle, S.A., Bennett, A.F., Taylor, N.M., Barton, H.A., 2008. Use of attenuated total reflectance fourier transform infrared spectroscopy to identify microbial metabolic products on carbonate mineral surfaces. Applied and Environmental Microbiology, 74, 4553-4559. https://doi.org/10.1128/AEM.02936-07

Carlson Jr, G.F., Woodard, F.E., Wentworth, D.F., Sproul, O.J., 1968. Virus inactivation on clay particles in natural waters. Journal of the Water Pollution Control Federation, R89-R106.

CDC (Center for Disease Control and Prevention), 2020. How to protect yourself and others. https://www.cdc. gov/coronavirus/2019-ncov/prevent-getting-sick/ prevention.html [accessed: June 3, 2020]

CDC Covid-19 Response Team, 2020. Severe outcomes among patients with coronavirus disease 2019 (COVID-19) - United States. Morbidity and Mortality Weekly Reports, 69, 343-346.

Chan, K.H., Peiris, J.S.M., Lam, S.Y., Poon, L.L.M., Yuen, K.Y., Seto, W.H., 2011. The effects of temperature and relative humidity on the viability of the sars coronavirus. Advances in Virology 2011, 734690.

https://doi.org/10.1155/2011/734690

Chander, Y., Johnson, T., Goyal, S.M., Russell, R.J., 2012. Antiviral activity of Ecasol against feline calicivirus, a surrogate of human norovirus. Journal of Infection and Public Health 5, 420-424.

https://doi.org/10.1016/j.jiph.2012.10.001

Courtemanche, C.J., Garuccio, J., Le, A., Pinkston, J.C., Yelowitz, A., 2020. Did social-distancing measures in kentucky help to flatten the COVID-19 curve? Working Paper 29. Institute for the Study of Free Enterprise, University of Kentucky, Lexington, KY, 23 p.

CoV-ICTV (Coronaviridae Study Group of the International Committee on Taxonomy of Viruses), 2020. The species Severe acute respiratory syndrome-related coronavirus: classifying 2019-nCoV and naming it SARS-CoV-2. Nature Microbiology 5, 536-544. https://.doi.org/10.1038/s41564-020-0695-Z

Cullinane Thomas, C., Koontz, L., 2020. 2019 National Park visitor spending effects: Economic contributions to local communities, states, and the nation. Natural Resource Report NPS/NRSS/EQD/NRR—2020/2110. National Park Service, Fort Collins, Colorado.

Dietz, L., Horve, P.F., Coil, D.A., Fretz, M., Eisen, J.A. and Van Den Wymelenberg, K., 2020. 2019 Novel coronavirus (COVID-19) pandemic: Built environment considerations to reduce transmission. mSystems, 5, e00245-00220. https://.doi.org/10.1128/mSystems.00245-20

Dong, E., Du, H., Gardner, L., 2020. An interactive webbased dashboard to track COVID-19 in real time. The Lancet, 20, 533-534.

https://doi.org/10.1016/S1473-3099(20)30120-1

Baquedano Estévez, C., Merino, L.M., de la Losa Román, A. and Durán Valsero, J.J. 2019. The lampenflora in show caves and its treatment: an emerging ecological problem. International Journal of Speleology, 48, 249277. https://doi.org/10.5038/1827-806X.48.3.2263

EPA (Environmental Protection Agency), 2020. List $\mathrm{N}$ : Disinfectants for Use Against SARS-CoV-2. https://www.epa.gov/pesticide-registration/list-ndisinfectants-use-against-sars-cov-2 [accessed: June 3, 2020].

Hershey, O.S., Barton, H.A., 2018. Microbial diversity in caves. In: Moldovan, O., Kovác, L., Halse, S. (Eds.), Ecological studies: Cave ecology. Springer, New York, NY. https://doi.org/10.1007/978-3-319-98852-8 5 
Imlay, J.A., 2008. Cellular defenses against superoxide and hydrogen peroxide. Annual Reviews of Biochemistry, 77, 755-776. https://doi.org/10.1146/annurev.biochem. 77.061606 .161055

James, A., Eagle, L., Phillips, C., Hedges, S., Bodenhamer, C., Brown, R., Wheeler, G., Kirking, H., 2020. High COVID-19 attack rate among attendees at events at a church - Arkansas. Mobidity and Mortality Weekly Reports, 69, 632-635.

https://doi.org/10.15585/mmwr.mm6920e2

Jean, J., Vachon, J.F., Moroni, O., Darveau, A., KukavicaIbrulj, I., Fliss, I., 2003. Effectiveness of commercial disinfectants for inactivating hepatitis A virus on agrifood surfaces. Journal of Food Protection, 66, 115-119. https://doi.org/10.4315/0362-028X-66.1.115

Kampf, G., Todt, D., Pfaender, S., Steinmann, E., 2020. Persistence of coronaviruses on inanimate surfaces and their inactivation with biocidal agents. Journal of Hospital Infection, 104, 246-251.

https://doi.org/10.1016/j.jhin.2020.01.022

Kim, S.W., Ramakrishnan, M.A., Raynor, P.C., Goyal, S.M., 2007. Effects of humidity and other factors on the generation and sampling of a coronavirus aerosol. Aerobiologia, 23, 239-248.

https://doi.org/10.1007/s10453-007-9068-9

Klaine, S.J., Alvarez, P.J.J., Batley, G.E., Fernandes, T.F., Handy, R.D., Lyon, D.Y., Mahendra, S., McLaughlin, M.J., Lead, J.R., 2008. Nanomaterials in the environment: Behavior, fate, bioavailability, and effects. Environmental Toxicology and Chemistry, 27, 1825-1851. https://doi.org/10.1897/08-090.1

Kozlowski, L.P., 2016. IPC - Isoelectric Point Calculator. Biology Direct, 11, 55.

https://doi.org/10.1186/s13062-016-0159-9

Krug, P.W., Lee, L.J., Eslami, A.C., Larson, C.R., Rodriguez, L., 2011. Chemical disinfection of highconsequence transboundary animal disease viruses on nonporous surfaces. Biologicals, 39, 231-235. https://doi.org/10.1016/j.biologicals.2011.06.016

Lakshminarayanaiah, N., Murayama, K., 1975. Estimation of surface charges in some biological membranes. Journal of Membrane Biology, 23, 279292. https://doi.org/10.1007/BF01870254

Lamarre, A., Talbot, P.J., 1989. Effect of $\mathrm{pH}$ and temperature on the infectivity of human coronavirus 229E. Canadian Journal of Microbiology, 35, 972-974. https://doi.org/10.1139/m89-160

Lim, M.Y., Kim, J.-M., Ko, G.P., 2010. Disinfection kinetics of murine norovirus using chlorine and chlorine dioxide. Water Research, 44, 3243-3251. https://doi.org/10.1016/j.watres.2010.03.003

Luiszer, F.G., 2009. Speleogenesis of Cave of the Winds, Manitou Springs, Colorado. Select Field Guides to Cave and Karst Lands of the United States, 15, 119-132.

Maillard, J.-Y., 2001. Virus susceptibility to biocides: an understanding. Reviews in Medical Microbiology, 12, 6374. https://doi.org/10.1097/00013542-200104000-00001

Maris, P., 1990. Virucidal efficacy of eight disinfectants against pneumovirus, coronavirus and parvovirus. Annals of Veterinary Research, 21, 275-279.

McDonnell, G., Russell, A.D., 1999. Antiseptics and disinfectants: activity, action, and resistance. Clinical Microbiology Reviews, 12, 147-179. https://.doi.org/10.1128/CMR.12.1.147

Meyer, E., Seale, L.D., Permar, B., McClary, A., 2017. The effect of chemical treatments on lampenflora and a collembola indicator species at a popular tour cave in California, USA. Environmental Management, 59, 1034-1042.

https://doi.org/10.1007/s00267-017-0842-3
Miller, G.L., Lauffer, M.A., Stanley, W.M., 1944. Electrophoretic studies on PR8 influenza virus. The Journal of Experimental Medicine, 80, 549-559. https://doi.org/10.1084/jem.80.6.549

Minoshima, M., Lu, Y., Kimura, T., Nakano, R., Ishiguro, H., Kubota, Y., Hashimoto, K., Sunada, K., 2016. Comparison of the antiviral effect of solid-state copper and silver compounds. Journal of Hazardous Materials, 312, 1-7. https://doi.org/10.1016/i.jhazmat.2016.03.023

Moore, R.S., Taylor, D.H., Sturman, L.S., Reddy, M.M., Fuhs, G.W., 1981. Poliovirus adsorption by 34 minerals and soils. Applied and Environmental Microbiology, 42, 963. https://doi.org/10.1128/AEM.42.6.963-975.1981

Mulec, J., Kosi, G., 2009. Lampenflora algae and methods of growth control. Journal of Cave and Karst Studies, $71,109-115$.

Murray, J.P., Parks, G.A., 1980. Poliovirus adsorption on oxide surfaces: correspondence with the DLVO-Lifshitz theory of colloid stability. In: Kavanaugh, M.C., Leckie, J.O. (Eds.), Particulates in water. ACS Publications, Washington, D.C., p. 97-133. https://doi.org/10.1021/ba-1980-0189.ch005

Nakano, H., Hiraoka, M., Sameshima, M., Kimura, T., Momoyama, K., 1998. Inactivation of penaeid rodshaped DNA virus (PRDV), the causative agent of penaid acute viremia (PAV), by some chemical and physical treatments. Fish Pathology, 15, 65-71. https://doi.org/10.3147/jsfp.33.65

Palmer, A.N., 2007. Cave geology. Cave Books, Dayton, $\mathrm{OH}, 454 \mathrm{p}$.

Parker, C.W., Auler, A.S., Barton, M.D., Sasowsky, I.D., Senko, J.M., Barton, H.A., 2018. Fe(III) reducing microorganisms from iron ore caves demonstrate fermentative $\mathrm{Fe}(\mathrm{III})$ reduction and promote cave formation. Geomicrobiology Journal, 35, 311-322. https://doi.org/10.1080/01490451.2017.1368741

Pekker, M., Shneider, M.N., 2015. Interaction between electrolyte ions and the surface of a cell lipid membrane. Journal of Physical Chemistry and Biophysics, 5, 21610398.https://doi.org/10.4172/2161-0398.1000177

Petrick, J.F., Chen, C.-C., 2013. National Caves Association: Evaluation. Texas A\&M University, College Station, TX, $20 \mathrm{p}$

Poli, G., Biondi, P.A., Uberti, F., Ponti, W., Balsari, A., Cantoni, C., 1979. Virucidal activity of organic acids. Food Chemistry, 4, 251-258. https://doi.org/10.1016/0308-8146(79)90012-8

Prather, K.A., Wang, C.C., Schooley, R.T., 2020. Reducing transmission of SARS-CoV-2. Science, 368, 1422-1424. http://doi.org/10.1126/science.abc6197

Pyrc, K., Dijkman, R., Deng, L., Jebbink, M.F., Ross, H.A., Berkhout, B. and Van der Hoek, L., 2006. Mosaic structure of human coronavirus NL63, one thousand years of evolution. Journal of Molecular Biology, 364, 964-973. https://doi.org/10.1016/j.jmb.2006.09.074

Rafat Husain, S., Cillard, J., Cillard, P., 1987. Hydroxyl radical scavenging activity of flavonoids. Phytochemistry, 26, 2489-2491. https://doi.org/10.1016/S0031-9422(00)83860-1

Ratnesar-Shumate, S., Williams, G., Green, B., Krause, M., Holland, B., Wood, S., Bohannon, J., Boydston, J., Freeburger, D., Hooper, I., 2020. Simulated sunlight rapidly inactivates SARS-CoV-2 on surfaces. The Journal of Infectious Diseases, 222 (2), 214-222. https://doi.org/10.1093/infdis/jiaa274

Rudnick, S.N., McDevitt, J.J., First, M.W., Spengler, J.D., 2009. Inactivating influenza viruses onsurfaces using hydrogen peroxide ortriethylene glycol at low vapor concentrations. American Journal of Infection Control, 37, 813-819.

https://doi.org/10.1016/j.ajic.2009.06.007 
Sánchez, G., Aznar, R., 2015. Evaluation of natural compounds of plant origin for inactivation of enteric viruses. Food and Environmental Virology, 7, 183-187. https://10.1007/s12560-015-9181-9

Santarpia, J.L., Rivera, D.N., Herrera, V., Morwitzer, M.J., Creager, H., Santarpia, G.W., Crown, K.K., BrettMajor, D., Schnaubelt, E., Broadhurst, M.J., Lawler, J.V., Reid, P., Lowe, J.J., 2020. Transmission potential of SARS-CoV-2 in viral shedding observed at the University of Nebraska Medical Center. Posted June 3, 2020 medRxiv.

https://doi.org/10.1101/2020.03.23.20039446

Sasowsky, I.D., Mylroie, J.E., 2004. Studies of cave sediments: Physical and chemical records of paleoclimate. Springer, New York, 322 p. https://doi.org/10.1007/978-1-4419-9118-8

Sattar, S.A., Springthorpe, V.S., 1996. Transmission of viral infections through animate and inanimate surfaces and infection control through chemical disinfection. In: Hurst, C.J. (Ed.), Modeling disease transmission and its prevention by disinfection. Cambridge University Press, Cambridge, p. 224-257.

Schwertmann, U., 1991. Solubility and dissolution of iron oxides. Plant and Soil, 130, 1-25.

https://doi.org/10.1007/BF00011851

Shelley, V., Kaiser, S., Shelly, E., Williams, T., Kramer, M., Haman, K., Keel, K., Barton, H.A., 2012. Strategies for the decontamination of equipment for Geomyces destructans, the causative agent of White-Nose Syndrome. Journal of Cave and Karst Studies, 75, 1-10. https://doi.org/10.4311/2011LSC0249

Somasundaran, P., Agar, G.E., 1967. The zero point of charge of calcite. Journal of Colloid and Interface Science, 24, 433-440. https://doi.org/10.1016/0021-9797(67)90241-X

Spate, A., Spate, J., 2014. World-wide show cave visitor numbers over the recent past: A preliminary study. In: Australian Cave and Karst Management Association $20^{\text {th }}$ Conference Proceedings, Waitoma Caves, New Zealand, p. 57-69.

Stadnytskyi, V., Bax, C.E., Bax, A., Anfinrud, P., 2020. The airborne lifetime of small speech droplets and their potential importance in SARS-CoV-2 transmission. Proceedings of the National Academy of Sciences USA, 117, 11875-11877.

https://doi.org/10.1073/pnas.2006874117

Tyan, K., Jin, K., Kang, J., 2019. Novel colour additive for bleach disinfectant wipes reduces corrosive damage on stainless steel. Journal of Hospital Infection, 103, 227-230. https://doi.org/10.1016/j.jhin.2018.09.012

Vajda, J., Weber, D., Stefaniak, S., Hundt, B., Rathfelder, T., Müller, E., 2016. Mono- and polyprotic buffer systems in anion exchange chromatography of influenza virus particles. Journal of Chromatography, A1448, 73-80. https://doi.org/10.1016/j.chroma.2016.04.047

van der Hoek, L., Pyrc, K., Jebbink, M.F., VermeulenOost, W., Berkhout, R.J.M., Wolthers, K.C., Wertheimvan Dillen, P.M.E., Kaandorp, J., Spaargaren, J.,
Berkhout, B., 2004. Identification of a new human coronavirus. Nature Medicine, 10, 368-373. https://doi.org/10.1038/nm1024

van Doremalen, N., Bushmaker, T., Morris, D.H., Holbrook, M.G., Gamble, A., Williamson, B.N., Tamin, A., Harcourt, J.L., Thornburg, N.J., Gerber, S.I. and Lloyd-Smith, J.O., 2020. Aerosol and surface stability of SARS-CoV-2 as compared with SARS-CoV-1. New England Journtal of Medicine, 382, 1564-1567. https://doi.org/10.1056/NEJMc2004973

Vemuri, G.N., Altman, E., Sangurdekar, D.P., Khodursky, A.B., Eiteman, M.A., 2006. Overflow metabolism in Escherichia coli during steady-state growth: transcriptional regulation and effect of the redox ratio. Applied and Environmental Microbiology, 72, 3653-3661.

https://doi.org/10.1128/AEM.72.5.3653-3661.2006

White, W.B., 2007. Cave sediments and paleoclimate. Journal of Cave and Karst Studies, 69, 76-93.

WHO (World Health Organization), 2020. Novel Coronavirus (2019-nCoV) Situation Report 22. https:// www.who.int/docs/default-source/coronaviruse/ situation-reports/20200211-sitrep-22-ncov.pdf [accessed: February 11, 2020].

Wigley, T.M.L., Brown, M.C., 1976. The physics of caves. In: Ford, T.D., Cullingford, C.H.D. (Eds.), The science of speleology. Academic Press, London, p. 329-347.

Wilson, L., 2020. SARS-CoV-2, COVID-19, Infection Fatality Rate (IFR) implied by the serology, antibody, testing in New York City. SSRN.

https://doi.org/10.2139/ssrn.3590771

Winterbourn, C.C., 1995. Toxicity of iron and hydrogen peroxide: the Fenton reaction. Toxicology Letters, 8283, 969-974.

https://doi.org/10.1016/0378-4274(95)03532-X

Wolff, M.H., Sattar, S.A., Adegbunrin, O., Tetro, J., 2005. Environmental survival and microbicide inactivation of coronaviruses. In: Schmidt, A., Wolff, M.H., Webe, O. (Eds.), Coronaviruses with special emphasis on first insights concerning SARS. Springer, pp. 201-212. https://doi.org/10.1007/3-7643-7339-3 10

Woo, P.C.Y., Lau, S.K.P., Huang, Y., Yuen, K.-Y., 2009. Coronavirus diversity, phylogeny and interspecies jumping. Experimental Biology and Medicine, 234, 1117-1127. https://doi.org/10.3181/0903-MR-94

Xu, B., Jahic, M., Blomsten, G., Enfors, S.O., 1999. Glucose overflow metabolism and mixed-acid fermentation in aerobic large-scale fed-batch processes with Escherichia coli. Applied Microbiology and Biotechnology, 51, 564-571. https://doi.org/10.1007/s002530051433

Yang, W., Marr, L.C., 2012. Mechanisms by which ambient humidity may affect viruses in aerosols. Applied and Environmental Microbiology, 78, 67816788. https://doi.org/10.1128/AEM.01658-12

Zhou, P., Yang, X.-L., Wang, X.-G., Hu, B., Zhang, L., Zhang, W., Si, H.-R., Zhu, Y., Li, B., Huang, C.-L., 2020. A pneumonia outbreak associated with a new coronavirus of probable bat origin. Nature, 579, 270273. https://doi.org/10.1038/s41586-020-2012-7 